\title{
Elements \\ of Organizational \\ Culture - theoretical and methodological problems
}

\section{Introduction}

In the literature, there are multiple concepts and models of organizational culture, which often lead to contradictory results (Sułkowski 2009). The proposition of cognitive analysis may be necessary for basic components of most models of organizational culture called cultural elements. Knowledge of the culture and ways of its manifestation should lead to greater coherence between the various empirical studies (Sułkowski 2002, 2008).

The purpose of this article is therefore the analysis of the various elements of organizational culture that are present in different concepts of culture. This is an important problem from the point of view of theory and practice of managing organizations because it is through research and development that culture can be managed, or at least influenced.

Prof. Łukasz Sułkowski Jagiellonian University University of Social Sciences
2. Models, components and types of organizational cultures

The key to understanding organizational culture are models and types of cultural elements that are interpreted differently. I suggest to take for the course of our 
analysis, that the functionalist elements of organizational culture will be strictly cultural variables, such as values, basic assumptions, norms, artifacts, etc. Model would, in turn, be the relationship between the relevant variables describing the organizational culture, which make it possible to predict the state of culture. Thanks to the following demands would be met: a causal relationship between variables and potential verifiability. This means that the model would give the ability to generate hypotheses concerning culture, and then using efficient methods, or at least possible to verify these hypotheses. The consequence would be to create a model of the generation of cultural typology (classification) of different types of culture, according to relevant criteria. By adopting such assumptions, you can start the analysis of the components, through models, to types of organizational culture and methodology of their research.

\section{Extracting elements of organizational culture}

According to the definition by A. Klosowska (2007) elementary components of culture can be regarded as values, norms and cultural patterns, developed and distributed in the social community. In relation to organizational culture this collectivity, which is based on a community of values, norms and cultural patterns, is the organization. The components of organizational culture began to be singled out by E. Schein, P. Bate, A. Pettigrew and the other authors are in the 70s of the twentieth century. In connection with the consolidation of certain divisions in the literature and the analysis of cultural adaptation to the practice of business should indicate the kind of "canon" of organizational culture elements including:

- cultural values,

- basic assumptions,

- social and organizational norms,

- ways to communicate, stories, narratives, myths and metaphors,

- organizational stereotypes,

- rituals,

- symbols

- customs,

- organizational heroes,

- taboo,

- cultural patterns,

- cultural artifacts,

- subculture. 


\section{From values to artifacts of the organizational culture}

The most basic concepts of values or assumptions, which include fundamental questions about the relationship to the organization (identity), a man in the organization, the nature of the environment and other "existential" questions remain the core of culture. From the values in turn stem the social norms, generally understood as shaping the behavior of members of the organization, which takes the form of injunctions or prohibitions. An important component of organizational culture are the means of communication that can be described by: stories, narratives, myths and metaphors. Stories, narratives and myths are informal, verbal descriptions provided by employees of actual or in case of myth myths, fantastic descriptions of the organizational reality of the past, reflecting the "spirit" (espirit du corp). As the well-documented studies indicate human cognitive apparatus is well prepared to absorb, remember, and even intuitive assessment of the narrative, and in particular those that are emotionally charged (Norenzayan, Atran, Faulkner, Schaller 2006, pp. 531-553). Probably because stories about: leaders of unusual activities, special events or dramatic situations are so well rooted in the "collective consciousness" of the organization. Rhetorical structure of these stories is usually simple, but very the parts of paradoxes, antinomies and metaphors are sued. Very important is also humor, often manifesting itself in suspense.

Another important element of organizational culture is a metaphor, which also reflects the essence of the organization. Deeply rooted in the minds of managers and other staff members they impinge on a view of the entire organization, social relations, and relations with the environment. For example, the use of organic metaphors could be affected by the management of the many manifestations of organizational life (Morgan 1999). There would also be, for example, the use of military metaphors of the free market and competition (Sułkowski 2009).

The next component analysis of organizational culture - ritual was taken directly from cultural anthropology and sociology. Rituals provide stagnant, rigid modes of action established in the organization. The ritual is the carrier of the cultural heritage, which is revealed by the symbolic, repetitive behavior of people (Pettigrew 1979). The most important include the rituals include: initiation (the treatment of new employees), transition (in case of change of roles), integration (measures to strengthen the identification of employees with the organization), degradation (ways of displaying the loss of prestige). Rituals serve important social functions, because they are on the one hand the message, and on the other hand, set standards of behavior. Adjustment 
becomes a very important aspect, because it shows employees how to "correct" operation without the need for reflection and decision-making every time. Organizational behavior inconsistent with the ritual are a source of cultural confusion and lead to the breakdown of organizational routines. Stereotypes are "functioning in the social consciousness simplified and valued pictures of reality" (PWN Polish Language Dictionary. T. 1-2, 2007). Social activities are largely carried out thanks to stereotypes, because they correspond to the elementary principle of economy of decision-making. Much of human perception and interpretation is done by assimilated stereotypes, which medium is the culture. Stereotypes are embeded in organizational culture in which there are simple, prescriptive regulations relating to all elements of social reality. These are the very stereotypical answers to questions about identity, relations, cooperation with others, which are reflected in other components of organizational culture (stories, rituals, language, etc.) and the organization (mission, vision, strategic goals, organizational structure). Moving away from functionalism, stereotypes in organizational culture can be compared to the schemes proposed by S.G. Harris. It is defined as the knowledge structure diagrams drawn from the experience and used to work in similar situations. S.G. Harris describes several types of such schemes rooted in the organizational culture. For example, "I'm in the organization" establishes the relationship between the unit and collective identity, and the "personality of the organization" integrates personal perceptions and memories of the expectations to the other members of the organization (Harris, 1994, pp. 309-321).

A symbol is a "thing, person, object, etc., or their image, which is a sign of something, evocative of a concept in mind and causing some - especially deep - the content" (PWN Polish Language Dictionary. T. 1-2, 2007). With regard to the organizational culture symbol is a sign that reflects cultural values. The functionalism narrows understanding of the symbol as a logo, trademark or color. From interpretativistic perspective it is very extended, as virtually everything in the organization may have a symbolic meaning (words, events, situations, characters, etc.).

The custom is " conducting, behaving in a fixed way, doing something in the community, often tradition." The custom in organizational culture are kinds of repetitive and petrified social practices that are similar to the ritual, but slightly different, kept in the collective consciousness, the desirability of social action. For example, the organizational practice can be "shared morning coffee" among employees. It has aspects of ritual, as it is petrified, on the other hand, employees have the correct diagnosis of meaningfulness and purpose of 
this action. In contrast to the ritual habit is usually not as rigid and is more focused on the individual, as well captures the Polish phrase "I have a habit." Heroes are important organizational form, which had a significant impact on the organization. Organizational heroes always include the founders, whose personality, ideas, and ideas are usually the primary source of culture. Other characters can be: management, managers and charismatic employees. Narratives about the characters and created by them customs and symbols may affect organizational culture trends. In the literature, there are a lot of publications on "personality of organization" and the problem of coupling between organizational culture and the people forming it (Chatman, Barsade 1995, pp. 423-443; Manfred Kets de Vries, Miller 1986, pp. 266-279).

Taboo is a term taken from the depths of psychology and previously and from Freud's psychoanalysis as well as cultural anthropology to describe a topic or social action, which is on the one hand concealed and motionless, and the other important organizations, and even the time-honored tradition (Freud 1999). Taboos are of interest to both functionalist (Vianen, Fischer 2002), as well as representatives of alternative paradigms (Martin 1990, pp. 339-359). For example, they are often used in connection with issues of discrimination and stigmatization of disadvantaged groups in organizations (Wilson 2000, pp. 274-303).

Cultural patterns are often interpreted through the prism of one of the most popular books anthropological like "Patterns of Culture" R. Benedict (Benedict 1966, p 386). The organizational culture will be a relatively fixed way of acting together by members of the organization, which is a manifestation of its configuration of values. Cultural patterns may relate to any action, so both ways of proper behavior in the organization are appropriate ways to communicate.

Artifacts are terms drawn from anthropology and archeology, which, in relation to organizational culture means visible manifestations of the functioning of the organizational culture in the form of physical (eg, space, buildings, architecture), behavioral (eg gestures of welcome, non-verbal communication), language (eg language conventions, styling in the statements) (Burszta 2008). The term "artifact" was popularized in relation to organizational culture by E. Schein, but unfortunately it carries a great deal of ambiguity. On the one hand, as in archeology, his understanding seems to be restricted to the visible, largely material manifestations of culture, on the other hand, however, following the example of cultural anthropology, the artifact is understood as all kinds of manifestations of the basic assumptions and values of the organizational culture. An additional challenge is the use of artifacts, both here in the functionalist and interpretative paradigm (Gagliardi 1990). 
This subculture inside the culture of society that can build their integration in opposition to the dominant culture of the organization (counterculture), or the search for autonomy. The crystallization is usually carried subcultures around the values which are not completely consistent with the culture of the organization (Hofstede 1998, pp.1-12). Examples include professional subcultures in hospitals, doctors, nurses, managers, and others. Subculture and counterculture are key concepts for the understanding of the cultural in a symbolic-interpretative paradigm (Jermier, Slocum, Fry, Gaines 1991, pp. 170-194).

\section{Problematic elements of cultural distinctions}

The advantage of this canon of elements is the analytical approach to the operationalization and testing of organizational practices and consistent distribution according to which the components of culture can be separated from other organizational subsystems, such as strategy and organizational structure. The disadvantage of this division is the functionalist incompleteness and blending of ingredients of culture. It seems pretty obvious to say that for instance mission or power structures are cultural. The mission expresses the values and identity of the organization and the structure of power is the dominant cultural model. However, in terms of functionalistic-systematic approach these two elements should be included according to the strategy and organizational structure. As is easy to see, even a superficial analysis reveals that elements of culture are inseparable. For example, standard, pattern, and the broader cultural artifact are largely overlapping meanings. All of the elements of organizational culture are systemically interdependent, but hierarchically structured. The causes and the primary components of culture are values and basic assumptions. Other elements of organizational culture are often considered only as a manifestation of the deeper elements . Some suggestions concerning the analysis of the culture, trying to avoid the disadvantages of the "canon" of components of culture are on the verge of understanding based on the functionalism and interpretativism. So G. Johnson (1988, pp. 75-91) suggests dividing the elements of culture that is inseparable and considers the strategy and structure as cultural elements. The proposal includes the following elements of the organizational culture:

- paradigm: what the organization is, what it does, what is its mission and its values,

- control systems: processes in order to monitor what is going on, 
- organizational structures: hierarchies and division of labor,

- structures of power: who decides and what are prerogatives,

- symbols: logo and utility models, but also status symbols denoting power,

- rituals and procedures of meetings, reports, established more than necessary,

- stories and myths: narratives about people and events to convey a message about what is valued in the organization.

It seems, however, that such extension of the understanding of culture is quite risky cognitively and methodologically. The inclusion of the strategy and organizational structure in culture means that you cannot treat them as equal subsystems organizational culture. In this case, the relationship between the sub-systems testing becomes irrelevant, and the idea is coming to the understanding of culture as a "metaphor core", which is characteristic only for non functionalistic paradigms.

\section{Summary}

The article analyzes different elements of organizational culture that can be identified in empirical research. 13 different types of cultural components were identified, ranging from values to organizational subcultures.

Rarely are there cultural models that use all of these types of cultural elements. On the other hand, while studying the organizational culture of diverse methods we can find descriptions of the various components of organizational culture. No severance and precision in defining the different cultural elements of organizing is probably one of the reasons of unclear theoretical concepts and problems of operationalization of the organizational culture. Therefore postulated solution prior to empirical research, is that it should be defined which elements in which cultural model would be operationalized in a particular study.

\section{Abstract}

\section{Elements of organizational culture - theoretical and methodological issues}

The purpose of this article is therefore the analysis of the various elements of organizational culture that are present in different concepts of culture. This is an important problem from the point of view of theory and practice of managing organizations because it is through research and development that culture can be managed, or at least influenced. The article analyzes different elements of organizational culture that can be identified in empirical research. 
13 different types of cultural components were identified, ranging from values to organizational subcultures.

Keywords: organizational culture, organizational culture elements, models of organizational culture

\section{Streszczenie}

\section{Elementy kultury organizacyjnej - problemy teoretyczne i metodologiczne}

Celem artykułu jest zatem analiza różnych elementów kultury organizacyjnych, które przewijają się w różnych koncepcjach kultury. Jest to problem istotny z punktu widzenia teorii i praktyki zarządzania organizacjami ponieważ, to właśnie poprzez badania i kształtowanie składników kultury można nią zarządzać, lub chociażby wywierać na nią wpływ. W artykule poddano analizie zróżnicowane elementy kultury organizacyjnej, które moga być identyfikowane $\mathrm{w}$ badaniach empirycznych. Wyróżniono 13 różnych rodzajów składników kulturowych, począwszy od wartości, aż do subkultur organizacyjnych.

Słowa

kluczowe: $\quad$ kultura organizacyjna, elementy kultury organizacyjnej, modele kultury organizacyjnej

\section{References}

1. Benedict R. (1966), Wzory kultury, PWN, Warszawa.

2. Burszta W.J. (2008), Antropologia kultury, Zysk i ska., Warszawa.

3. Chatman A.J., Barsade S.G. (1995), Personality, Organizational Culture, and Cooperation: Evidence from a Business Simulation, "Administrative Science Quarterly", Vol. 40, No. 3.

4. Freud S. (1999), Totem And Taboo, Some Points of Agreement between the Mental Lives of Savages and Neurotics, Routledge.

5. Gagliardi P. (1990), Symbols and Artifacts: Views of the Corporate Landscape Communication and Social Order, Transaction Publishers.

6. Harris S.G. (1994), Organizational Culture and Individual Sensemaking: A Schema-Based Perspective, "Organization Science", Vol. 5,(3).

7. Hofstede G. (1998), Identifying Organizational Subcultures: An Empirical Approach, "Journal of Management Studies", 35.

8. Jermier J.M., Slocum J.W., Jr., Fry L.W. (1991), Gaines, Organizational Subcultures in a Soft Bureaucracy: Resistance behind the Myth and Facade of an Official Culture, "Organization Science", Vol. 2, No. 2. 
9. Johnson G. (1988), Rethinking Incrementalism, "Strategic Management Journal", Vol 9.

10. Kłoskowska A. (2007), Socjologia kultury, PWN, Warszawa.

11. Manfred F., Vries R. Kets de, Miller D. (1986), Personality, Culture, and Organization, "The Academy of Management Review", Vol. 11, No. 2.

12. Martin J. (1990), Deconstructing Organizational Taboos: The Suppression of Gender Conflict in Organizations, "Organization Science", vol. 1 no. 4.

13. Morgan G. (1999), Obrazy organizacji, PWN, Warszawa.

14. Norenzayan A., Atran S., Faulkner J., Schaller M. (2006), Memory and Mystery: The Cultural Selection of Minimally Counterintuitive Narratives, "Cognitive Science", 30.

15. Pettigrew A.M. (1979), On Studying Organizational Culture, Administrative Science Quarterly, No. 12.

16. Słownik języka polskiego PWN. T. 1-2 (2007), Wydawnictwo Naukowe PWN.

17. Sułkowski Ł., The problems of epistemology of corporate culture, "Journal of Intercultural Management", Volume 1, Number 1, April 2009.

18. Sułkowski Ł., Czy warto zajmować się kultura organizacyjna?, "Zarządzanie Zasobami Ludzkimi", nr 6, 2008.

19. Sułkowski Ł., Czy kultury organizacyjne zmierzaja do unifikacji?, w: "Zarządzanie Zasobami Ludzkimi", Instytut Pracy i Spraw Socjalnych, nr 3-4, 2002.

20. Vianen A.E.M. van, Fischer A.H. (2002), Illuminating the glass ceiling: The role of organizational culture preferences, "Journal of Occupational and Organizational Psychology".

21. Wilson E. (2000), Inclusion, exclusion and ambiguity - The role of organizational culture, "Personnel Review", Vol. 29 Iss: 3. 